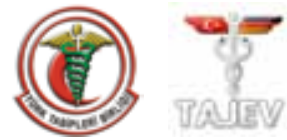

\title{
Evaluation of ovarian reserve in infertile patients
}

\section{infertil hastalarda over rezervinin değerlendirilmesi}

\author{
Mehmet Firat Mutlu', Ahmet Erdem² \\ 'Department of Gynecology and Obstetrics, HRS Ankara Women Hospital, Ankara, Turkey \\ ${ }^{2}$ Department of Gynecology and Obstetrics, Faculty of Medicine, Gazi University, Ankara, Turkey
}

\section{Abstract}

Diminished ovarian reserve is a more common occurrence as more women postpone childbearing in modern societies due to social and demographic trends. Diminished ovarian reserve is one of the primary reasons for poor ART outcome. Due to high costs, side effects and heavy burden on patients on ART treatments, patient selection and counseling for prognosis is an important aspect before starting ART. Proper prediction of ovarian reserve before initiation of the treatment can decrease cycle cancellations, help clinicians to establish alternative treatment options (i.e.oocyte donation) for poor prognosis patients. However, indicators of ovarian reserve are not fully successful in predicting the outcome of the treatment. In this review, our aim was to discuss the efficacy of ovarian reserve tests on predicting poor ovarian response and treatment outcome in ART patients.

(J Turkish-German Gynecol Assoc 2012; 13: 196-203)

Key words: ART, ovarian reserve, poor ovarian response, cycle cancellation, treatment

Received: 23 July, 2012

Accepted: 13 August, 2012
Özet

Günümüzde modern toplumlarda kadınların evliliklerini çeşitli nedenlerle geciktirmesi nedeniyle düşük over rezervi ile daha sık karşılaşılmaktadır. ART tedavisi sırasında düşük over reservi başarııı azaltan başlıca nedenlerden birisidir. Tedavilerin maliyeti, yan etkileri, hasta açısından zorluklanı göz önüne alındığında uygun hasta seçimi ve uygun prognoz belirlenmesinin oldukça önemli olduğu görülmektedir. Tedavi öncesi ovaryen yanıtın öngörülmesi ile yetersiz ovaryen yanıt nedeniyle siklus iptalleri azaltılabilmekte; aynı zamanda hekime uygun tedavi stratejileri geliştirme ve kötü prognozlu hastaları alternatif yöntemlere (oosit donasyonu) yöneltmeyi sağlayabilmektedir. Günümüzde bu amaçla kullanılan birçok belirteç mevcuttur. Ancak bu belirteçler tedaviye verilen yanıt hakkında fikir verse de hiç birisi tek başına tedavi başarısını göstermede tam güvenilir değildir. Bu derlemede ART tedavisi alan hastalarda kötü ovaryen yanıtı ve başarıyı ön görmede kullanılan over rezerv testlerinin etkinliği tartışılmaktadır. (J Turkish-German Gynecol Assoc 2012; 13: 196-203)

Anahtar kelimeler: ART, over rezervi, kötü ovaryen yanıt, siklus iptali, tedavi

Geliş Tarihi: 23 Temmuz 2012

Kabul Tarihi: 13 Ağustos 2012

\section{Introduction}

In modern societies, an increasing proportion of women delay marriage for various reasons and attempt to have their first pregnancies at a more advanced age (1). However, their chance of becoming pregnant begins to decline in this period of reproduction. The incidence of subfertility gradually increases with female partner age as $6 \%$ at age 20 to $24,9 \%$ at age 25 to $29,15 \%$ at age 30 to $34,30 \%$ at age 35 to 39 and $64 \%$ at age 40 to 44 (2). According to data derived from natural populations without contraception, fecundity is halved at 35 years as compared to 25 years of age; thus, 35 years of age in women is considered to be the age when the decline in fertility becomes more pronounced $(3,4)$.

Other factors associated with impaired fertility may augment the effect of aging on fertility in women. These are increased incidence of conditions such as endometriosis, myomas and pelvic inflammatory disease with age, as well as decreased frequency of coitus and increased incidence of male infertility in older couples. To control the effect of the male factor and coital frequency on impaired fertility, data from donor insemination studies can be used. In a donor study, female partners of men with azoospermia who were supposed to be comparable in reproductive health to fertile women have been inseminated with normal donor sperms and a cumulative pregnancy rate of $74 \%$ for one year was noted in women under 31 years of age as compared to $54 \%$ in women over 35 years of age (4). Data from another insemination program revealed a $3.5 \%$ decrease per year in the probability of having a healthy child in women after the age of 30 (5).

\section{Physiology of Reproductive Aging}

The probable theoretical causes of decline in reproductive potential in women beginning at the third decade of life may be classified as:

i. Diminished ovarian reserve

a. Quantitative decrease in oocytes

b. Qualitative changes in oocytes

ii. Diminished uterine receptivity for implantation

The diminished ovarian reserve, either by decreased quantity and/or quality of the resting follicle pool, might decrease fertility after age 30 . There is enough evidence for both situations. 
The primordial follicle count, which is about 20 millions at the $20^{\text {th }}$ week of intrauterine life, starts to decrease with the process of apoptosis (6-8). The primordial follicles left are about 1 million at birth and 300 thousands at puberty. At a mean age of 37-38 years only about 25 thousands of follicles are present in the ovaries. After this age, the disappearance of the follicles accelerates and the curve follows a biphasic pattern (7). The time interval between the beginning of accelerated follicular disappearance and menopause is constant at about thirteen years (7). Menstrual cycles become irregular about 6 years before menopause (9). There is a time period of about 4 years between age 37 when fertility begins to decline and age 41 when fertility practically ends (10).

It is known that the age of menopause in the general population is under 45 in $10 \%$ of women and under 40 in $1 \%$ of women (11). Thus, if the time interval between the beginning of accelerated follicular disappearance and menopause is constant and about thirteen years it can be speculated that about $10 \%$ of women in the general population will suffer from the clinical consequences of impaired fertility in their thirties due to early ovarian aging.

The data from ART cycles with fresh and nondonor oocytes and embryos demonstrate a decrease in embryo implantation, pregnancy and live birth rates per cycle when female partner age exceeds 38 (12). In ICSI cycles of men with obstructive azoospermia, the implantation rate decreases if the female partner age is over 37; this finding also demonstrates the effect of age related decline in oocyte quality on reproductive performance (13). Data obtained from oocyte donation clearly shows that, if oocytes are donated from young women to older women, both embryo implantation and pregnancy rates are restored to normal levels (14). These results suggest that the effect of age on fertility is largely a result of qualitative changes within the aging oocytes, rather than senescent changes in the uterus.

The high rates of pregnancy wastage in older women also indicate the age-related decrease in oocyte quality (15-17). Detection of high abortion rates in oocyte donation cycles if oocytes are donated from older women demonstrates that the age-related factor responsible for pregnancy wastage is also oocyte quality (18). An increased frequency of abnormal chromosome arrangements in human oocytes in older women is reported in several studies $(19,20)$. Preimplantation genetic diagnosis of embryos in women over 38 shows high rates of aneuploidy, another important evidence of a strong association between advanced maternal age and pregnancy wastage (21).

\section{Evaluation of ovarian reserve in infertile patients}

An important group of patients that has to be taken into consideration for diminished ovarian reserve are infertile women of advanced age $(>35)$. The proportion of older age infertile women is gradually increasing. Other risk factors for diminished ovarian function in infertile patients are summarized in Table 1.

If $10 \%$ of patients enter menopause before the age of 45 , then the same proportion of women are expected to experience signs of ovarian aging in their early thirties. Thus, it should be reasonable to test all infertile women over 30 for ovarian reserve. Ovarian surgeries of any kind, but particularly for ovarian endometriosis, might be detrimental to primordial follicle pool; thus, patients with a history of ovarian surgery need to be evaluated for ovarian reserve regardless of their age. The underlying cause of subfertility might theoretically be a subtle diminished ovarian reserve. For this reason, it will be reasonable to apply ovarian reserve tests liberally to unexplained infertile couples. The patients in whom ovarian reserve tests are indicated are summarized in Table 2.

The effect of diminished ovarian reserve on fertility outcome has largely been evaluated in patients treated with ART. In this group of infertile patients the clinical entities associated with diminished ovarian reserve are poor response to $\mathrm{COH}$, increased need for exogenous gonadotropins, high cancellation rates, low pregnancy and live birth rates in ART.

On the other hand, data regarding the reproductive outcome of ovulatory women in a general infertility population with an abnormal ovarian test is insufficient. Hence, the treatment alternatives to increase the chance to have a baby, especially in patients with an abnormal ovarian reserve test and younger than 35 years of age, are not yet known.

\section{Ovarian reserve tests}

The ovarian reserve tests are summarized in Table 3. Some of these tests have only been used for research and have not attained common practice.

\section{Basal follicle stimulating hormone (FSH) level}

Basal or cycle day 3 FSH level is an indirect indicator of ovarian reserve. It reflects the negative feedback effects of inhibin-B and estradiol produced by a cohort of follicles at pituitary level. Most of the studies of basal FSH levels are from ART cycles. The cut-off values for basal FSH vary from 10 to $25 \mathrm{IU} / \mathrm{l}$. The value of basal FSH as a test for ovarian reserve in ART was evaluated

Table 1. Patients groups at high risk for diminished ovarian reserve

\begin{tabular}{|ll|}
\hline 1. & Family history of early menopause \\
\hline 2. & Past chemotherapy \\
\hline 3. & Past radiotherapy \\
\hline 4. & Past pelvic surgery \\
\hline 5. & History of pelvic infection or tubal disease \\
\hline 6. & History of severe endometriosis \\
\hline 7. & Smoking \\
\hline
\end{tabular}

Table 2. Which groups of infertile patients need ovarian reserve tests?

\begin{tabular}{|ll|}
\hline 1. & Patients over 30 \\
\hline 2. & Patients with a history of ovarian surgery \\
\hline 3. & Patients with a history of surgery for severe endometriosis \\
\hline 4. & Unexplained infertility \\
\hline 5. & Poor response to ovarian stimulation \\
\hline
\end{tabular}


Table 3. Ovarian reserve tests

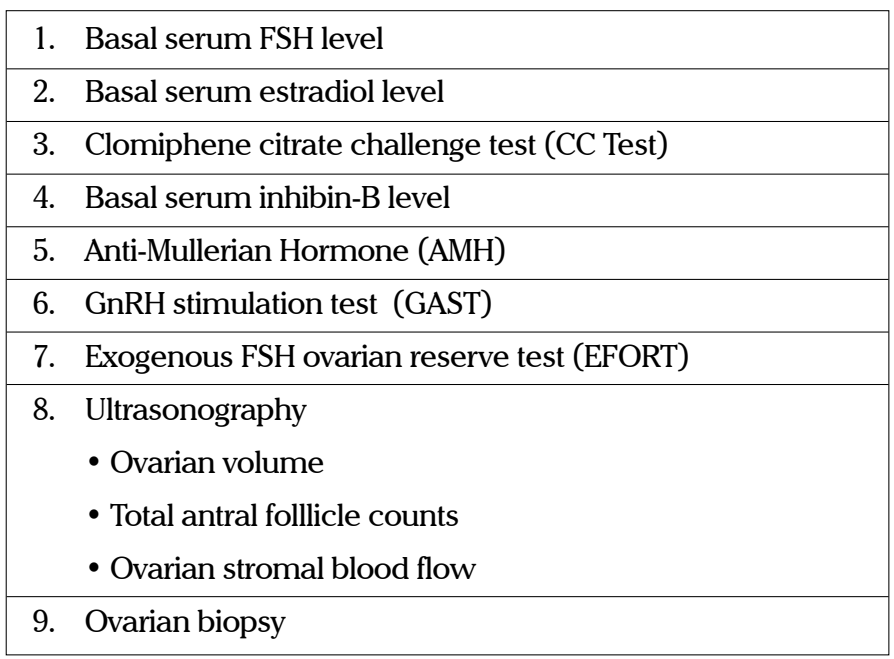

in a meta-analysis of 21 studies (22). The results of receiveroperating curve (ROC) analysis have shown that the performance of basal FSH in ART cycles to predict poor response was moderate, whereas to predict non-pregnancy was poor. In a systemic review, Broekmans et al. (23) found that the cut off FSH levels of $>10 \mathrm{U} / \mathrm{L}$ had a specificity of $80-90 \%$ and a lower sensitivity of $10-30 \%$ for the prediction of poor ovarian response to gonadotropins in IVF. The lack of a clear cut-off point with reasonable sensitivity and specificity and inter-cycle variations of FSH measurements also limits the reliability and use of basal FSH in IVF practice. The increase in basal FSH levels is a late indicator of ovarian reserve. Median FSH remained consistently low $(\leq 5 \mathrm{U} / \mathrm{L})$ in women $\leq 35$ years of age and was $6 \mathrm{U} / \mathrm{L}$ in 35 - to 40-year-olds (24). Prediction of over reserve with only basal FSH may lead to an inappropriate startegy in infertile women, and some with an diminished ovarian reseve cannot take advantage of determining the rapidly closing window of opportunity. Although it is known that the prognosis of ART cycles will be highly negative in patients with high basal FSH levels, it is generally accepted that the predictive value of FSH levels below cut-off values are limited to reflect the outcome of ART cycles. A study evaluating the predictive value of FSH with regard to age showed that the ART performance of the patients over 40 but with normal basal FSH levels were worse than the patients below 40 but with an abnormal basal FSH level (25). That is to say, age reflects oocyte quality whereas basal FSH reflects oocyte number and the outcome of an ART cycle will be better if oocytes can be retrieved despite high basal levels in younger patients. A normal basal FSH level does not negate the effects of chronologic age on oocyte quality, embryo implantation, and pregnancy rates, and expectations should be managed accordingly.

There are only a limited number of studies in which ovarian reserve tests were used to predict fertility prognosis in a general infertility population (26-28). In one of these studies, the predictive value of elevated basal FSH levels during the initial subfertility workup with respect to fecundity has been assessed in a general infertility population (28). Long-term follow-up has shown that the pregnancy rates and time interval to pregnancy were not different between patients with either normal or high basal FSH levels. It was concluded that screening for high basal FSH levels was of no additional value in a general infertile population.

\section{Basal estradiol levels}

Early elevations in serum estradiol reflect the advanced follicular development and early selection of a dominant follicle $t$ driven by rising FSH levels. A premature estradiol elevation may suppress the FSH levels, masking elevation that might otherwise reveal a low ovarian reserve. Patients with basal estradiol levels of $80 \mathrm{pg} / \mathrm{ml}$ or higher during a cycle before IVF achieved a lower pregnancy rate per initiated cycle (14.8\% versus $37.0 \%)$ and had a higher cancellation rate (18.5\% versus $0.4 \%)$, compared with those with estradiol levels below $80 \mathrm{pg} / \mathrm{ml}$. Even if FSH $>15$ were excluded, elevated basal estradiol levels still correlated with poor ovarian response and higher cancellation rates (29). As an ovarian test basal estradiol level has little value but may provide additional data in basal FSH interpretation. Adding cycle day 3 estradiol measurement to FSH decreases the incidence of false-negative results based on FSH alone.

\section{Clomiphene Citrate Challenge Test (CCC Test)}

The physiological basis of the CCC test is that, in a group of patients with diminished ovarian reserve but normal FSH levels, CC induced serum FSH rise cannot be suppressed by decreased inhibin secretion from a decreased primordial follicle pool and elevated levels of FSH are measured after CC administration. The test is considered abnormal if any measurement of FSH either on day 3 or on day 10 after CC administration is higher than $10 \mathrm{IU} / \mathrm{l}$. The predictive value of an abnormal CCC test is extremely high with an overall cumulative pregnancy rate of only $1.3 \%$, which is comparable with the $1.5 \%$ cumulative pregnancy rate among women with abnormal day 3 FSH values in ART cycles (30). Nevertheless, among older, atrisk patients, the CCC test also identified $29 \%$ of patients with compromised fecundity as compared to a rate of $6 \%$ for basal FSH screening alone (30). The use of the CCC test for screening ovarian reserve in a general infertile population was assessed only in a large series (26). About $10 \%$ of infertile women had an abnormal CCC test result and the fecundity of patients with an abnormal test was extremely decreased.

\section{Basal inhibin -B levels}

Inhibin- $B$ is a dimeric peptide that is secreted by granulosa cells of preantral and early antral follicles (31). Therefore it is thought to have some value as an ovarian test. Inhibin- B concentrations decline before a rise in basal FSH levels and thus shows the reduction of in ovarian reserve earlier than basal FSH (32, 33). As the level of inhibin-B decreases, ovarian response to gonadotropins, the number of oocytes retrieved and pregnancy rates decrease (34). Although there is a correlation between basal inhibin-B levels and ovarian response, it has low sensitivity $(60-90 \%)$, specifity $(40-80 \%)$ and positive predictive value (19-22\%) even in low threshold values $(40-45 \mathrm{pg} / \mathrm{mL}$ ) (35). In various studies investigating the relationship between basal inhibin-B and ART outcomes, it was concluded that inhibin-B level was not a reliable measure of ovarian reserve and had a poor predictive value for pregnancy (36-39). 


\section{Anti-Mullerian Hormone (AMH)}

Anti-mullerian hormone is produced by granulosa cells of preantral and small antral follicles. The secretion begins from the start of primordial follicle growth and continues until the follicles have become capable of responding to $\mathrm{FSH}$, which occurs when the diameter of the follicle reaches 4-6 mm (40). $\mathrm{AMH}$ is not expressed in atretic follicles and theca cells (41). The gonadotropin independent expression of $\mathrm{AMH}$ results of minimal variation within and between cycles provides advantage over other ovarian reseve markers. Pregnancy, the use of gonadotropin agonists for ovarian suppression, the day of menstrual cycle dose do not affect serum levels (42).

$\mathrm{AMH}$ expression is observed as early as the $36^{\prime}$ gestational week, serum levels are gradually increased in the first 3-4 years of life and become stable until puberty. As the number and quality of the oocytes diminish throughout the woman's reproductive life, serum concentrations of AMH gradually decrease and fall below detectable levels in the menopause (43). Median time of menopause can be predicted by using AMH levels more accurately than inhibin and basal FSH (44).The number of the residual follicular pool correlates with the number of small antral follicles and AMH levels (45-48).

The first study investigating the relation between AMH levels and ovarian response to gonadotropins on ART cycles was performed in 2002. From that time on numerous studies have been performed. In women undergoing ART, low AMH threshold values $(0.2-0.7 \mathrm{ng} / \mathrm{mL})$ have $40-97 \%$ sensitivity, $78-92 \%$ specifity, $22-88 \%$ positive predictive value and $97-100 \%$ negative predictive value for prediction poor response to stimulation, but do not predict pregnancy (49-52). Almost all studies revealed that there had been a correlation between AMH levels and retrieved oocyte number and AMH seems to be a better marker than age, basal FSH, estradiol, inhibin-B in predicting ovarian response to gonadotropins but, when compared with $\mathrm{AFC}$, it has nearly the same capacity to predict ovarian response (53). In a recent study including 1043 IVF cycles, AMH levels were found to be significantly related with the rate of on going pregnancy both in fresh and frozen embryo transfer cycles (54). In a meta-analysis, a total of 13 studies were analyzed reporting on $\mathrm{AMH}$ and 17 on $\mathrm{AFC}$ and it was shown that AMH had at least the same level of accuracy and clinical value for the prediction of poor response and non pregnancy as AFC. Both $\mathrm{AMH}$ and AFC have limited accuracy for non pregnancy prediction (55). Besides retrieved oocyte number, AMH and AFC are also found to be comparable predictors of the number of good quality embryos available for transfer and freezing (56).

However, $\mathrm{AMH}$ determination has some advantages over AFC: 1) It does not have to be carried out on a specific day of the cycle because of stability in serum levels throughout the menstrual cycle. 2) There is no need for a skilled ultrasound operator to count ovarian follicles 3) A possible observer bias in ultrasonographer is eliminated.

In their study, Silberstein at al. (57) found that the serum AMH levels at the time of hCG administration seem to predict not only ovarian reserve, but also embryo morphology. Some studies in the literature have revealed that there is a correlation betweeen oocyte quality and AMH levels (58-61) but other studies have defended the opposite $(39,62)$.

\section{GnRH stimulation test (GAST)}

Administration of GnRH agonists on cycle day 2-3 causes an initial surge of FSH, LH and estradiol. The response of estradiol is an indirect indicator of ovarian reserve. If the follicular cohort is small, GnRH agonists may lead to less estradiol increase. In two prospective studies it is shown that the response of estradiol to GnRH-a stimulation was highly correlated with ovarian response in ART cycles $(63,64)$.

\section{Exogenous FSH ovarian reserve test (EFORT)}

In the exogenous FSH reserve test, FSH and estradiol, inhibin levels are determined before and 24 hours after administration of 300 IU recombinant FSH on day 3 of the menstrual cycle. Basal FSH and levels and increase in estradiol levels are used to predict ovarian response in ART cycles. In a prospective study investigating the predictive value of EFORT in 52 IVF cycles it was shown that at least $30 \mathrm{pg} / \mathrm{mL}$ increase in estradiol levels is a better predictor of ovarian response than basal FSH (65). In another prospective randomized study performed by Kwee et al. (66) CCCT and EFORT were compared in terms of ovarian response in 110 ART cycle and it was found that the inhibin $B$ increment and estradiol increment in the EFORT are the best predictors of the total number of follicles obtained after maximal ovarian hyperstimulation in an IVF treatment; CCCT, basal FSH and estradiol, age show a much lower performance. EFORT and GAST are more complex, expensive and time consuming and the predictive value in ovarian response or pregnancy are not so different from conventional markers. It is not advised to use these tests routinely in the evaluation of ovarian reserve (35).

\section{Assessment of ovarian reserve by ultrasonography}

Comparison of an indirect assessment of ovarian reserve by sonographic measurement of ovarian volume and antral follicle counts with other ovarian reserve tests in ART cycles and their performance to predict response to $\mathrm{COH}$ and pregnancy rates have recently been reported in many studies. The most important advantage of ultrasonography is that it can be done in every patient without any additional cost. The sonographic assessment of ovarian reserve is also advantageous in selecting poor responders and choosing appropriate stimulation protocols at the beginning of the cycle.

\section{i. Measurement of ovarian volume}

The age-related decline in primordial follicle pool is supposed to cause a decrease in ovarian volume. The decrease in ovarian volume is supposed to be more pronounced after the age of 38 till menopause, a time period when the follicular depletion is accelerated. In a study population of women 14 to 45 years of age attending a family planning clinic, no correlation has been detected between age and ovarian volume (67). In a study with healthy and fertile Chinese women it was found that the ovarian volume was not different throughout the whole reproductive period (68). In a similar study population, but in the age group 
of 35 to 50 years, the mean ovarian volume was detected to be similar in three age groups of 35 to 39,40 to 44 and 45 to 49 years and the correlation of decrease in ovarian volume was evident only in the age group of 45 to 49 (69). Interestingly it was found in the same age groups that ovarian volume was decreased in infertile women compared to age-matched fertile women (70). Although the ovarian volume was least in unexplained infertile patients, the difference did not reach significance.

Data on the predictive value of ovarian volume measurement on IVF cycles has demonstrated that although a correlation between response to $\mathrm{COH}$ and ovarian volume was present, the predictive value of ovarian volume measurement for pregnancy was poor (71-74). High cancellation rates have also been reported in women with ovaries measuring less than $3 \mathrm{~cm}^{3}(71,72)$.

\section{ii. Antral follicle counts}

The age-related decline in the number of antral follicles less than $10 \mathrm{~mm}$ measured by ultrasound has been shown in several studies $(68,69,74)$. In a study population of fertile women a biphasic pattern has been demonstrated in age related decline in antral follicle counts (75). A yearly decline of $4,8 \%$ before the age of 37 was accelerated thereafter to the rate of $11.7 \%$. However, a monophasic yearly decline of $3,8 \%$ has been demonstrated in a fertile population in another study (68).

The correlation of antral follicle counts with poor response in IVF has been several studies $(74,76,77)$. In a recent study investigating the role of AFC in IVF outcome prediction, it has been shown that antral follicle count was predictive of ovarian response, with a $67 \%$ likelihood of poor ovarian response for $\mathrm{AFC} \leq 4$, also there was a significant linear relationship between AFC, age and live birth which is much more marked for AFC (78). A study comparing the effectiveness of basal and $\mathrm{CC}$ induced inhibin-B and FSH, ovarian volume and antral follicle counts to predict the outcome of IVF cycles, reported that ovarian volume was the best parameter to predict poor ovarian response to $\mathrm{COH}$, whereas age and antral follicle counts were found to be better than the other test with respect to predicting pregnancy success (74). In conclusion, it can be suggested that antral follicle counts reflect the ovarian reserve better than ovarian volume in infertile patients.

\section{iii. Ovarian stromal blood flow}

There is a positive and independent correlation between ovarian stromal peak systolic velocity (PSV) measured by transvaginal pulsed Doppler ultrasonography both in the early follicular phase and after pituitary suppression (79, 80). Engman et al. (79) showed that ovarian stromal PSV was the most important single independent predictor of ovarian response in patients with a normal basal serum FSH level, compared to age, FSH/ $\mathrm{LH}$ ratio, estradiol levels if the the cut-off level for PSV was taken as $10 \mathrm{~cm} / \mathrm{s}$. A study using 3D ultrasound reported that ovarian stromal vascularity was associated with a higher number of retrieved oocytes and increased pregnancy rates (81). Contrary to this Jarvela et al. (82) reported quantification of power Doppler signal in the ovaries after pituitary suppression does not provide any additional information to predict the subsequent response to gonadotrophin stimulation during IVF.
In a recent study, early follicular stromal Doppler signals is correlated with ovarian response and basal ovarian reserve parameters, but has no correlation with age or with clinical pregnancy achievement in infertile women undergoing IVF-ET treatment (83). Further studies are needed to clarify the effect of ovarian stromal blood flow on ART outcomes.

\section{Ovarian Biopsy}

Demonstration of primordial follicles depletion in the ovary by ovarian biopsy was studied by several authors. Lass et al. (84) in their investigation attempted to find if there had been correlation between basal estradiol levels, ovarian size and follicular density in 60 infertile women. Computerized image analysis was used to measure the number of follicles per unit volume of ovarian tissue. There was no significant difference between unexplained and tubal infertility patients. They also observed that follicular density diminished significantly with increasing age. A study assessing the accuracy of basal FSH, estradiol, CCCT, GAST in predicting the total number of follicles, which was determined by histological examination of oopherectomy materials in 22 fertile patients older than 35 years, found a positive correlation between only basal estradiol levels and follicle per unit but not with others (85). The uneven distribution of follicles in the ovary makes a large variation even in the same ovary (86). When the random follicular distributon and potential risks of procedure are taken into consideration together, this procedure is not justified on current available data.

\section{Combination of ovarian reserve tests}

None of the tests has a 100\% sensitivity and specifity used for poor ovarian response prediction. In order to increase the prognostic reliability of each test, combining the ovarian tests may be considered. A scoring system using the combination of age, AFC, basal FSH, basal AMH, delta E2 and delta inhibin developed by Muttukrishna et al. (87) predicted the ovarian response more accurately than each of the parameters alone. However, in a meta-analysis investigating the performance of the combinations of ovarian reseve tests to predict ovarian response in IVF, the combination of these tests did not perform better compared with AFC alone. According to this meta-analysis there is no advantage in using multivariate model in poor response prediction (88). Addition of age, AFC, basal FSH, inhibin to $\mathrm{AMH}$ did not make a significant difference in prognostic reliabiity of $\mathrm{AMH}$ in a recent study (89). The high level correlation of ovarian reserve tests and the differences of chosen thresholds for each test makes analysis diffucult.

Although ovarian reserve tests reflect oocyte quantity they do not reflect oocyte quality accurately (90). Age was found better in predicting pregnancy than these tests (90). Women with low ovarian reserve still have a reasonable chance to achieve pregnancy. The increased rates of spontaneous abortus and aneuploidy in young women with poor ovarian reserve suggest that oocyte quality may also contribute in some unexplained infertile women. Counseling and management of the cycle with the knowledge gained only from the ovarian reserve tests is a matter of debate. In fact, many women whose tests results were lower than the cut-off could have pregnancy after IVF. 


\section{Conclusion}

Assessment of ovarian reserve should not be neglected in an infertile patient if the age of the patient is above the period when the ovarian reserve is known to be declining.

At present, there is no ideal ovarian reserve test reflecting fertility potential of a woman reliably. Controversial results of the studies make it difficult to compare the efficiency of different tests of ovarian reserve. Data obtained from ART cycles are useful to form models for assessing the efficiency of various tests to predict fertility potential.

None of the tests of ovarian reserve is ideal to predict pregnancy. A woman with an abnormal ovarian test may conceive either spontaneously or by ART.

Although the predictive value (specificity) of an abnormal hormonal parameter (basal or CC induced FSH and inhibin) to detect diminished ovarian reserve is high, their sensitivities are low. The CC test is relatively more sensitive than basal FSH. Among the ultrasound parameters, an antral follicle count is the most reliable.

There are only a limited number of studies in which ovarian reserve tests were used to predict fertility prognosis in a general infertility population. The most reliable tests in these patients seem to be $\mathrm{AFC}$ and $\mathrm{AMH}$, according to the existing data. The studies in this group of patients will aid in forming screening strategies for asymptomatic cases of diminished fertility due to early ovarian aging in the general population.

AMH has advantages compared with other markers of ovarian reserve tests. It is the earliest marker to change with age and has least inter and intra cycle variability.

\section{Conflict of interest}

No conflict of interest was declared by the authors.

\section{References}

1. te Velde ER, Pearson PL. The variability of female reproductive ageing. Hum Reprod Update 2002: 8; 141-54. [CrossRef]

2. Menken J, Trussell J, Larsen U. Age and infertility. Science 1986; 233: 1389-94. [CrossRef]

3. O'Connor KA, Holman DJ, Wood JW. Declining fecundity and ovcarian ageing in natural fertility populations. Maturitas 1998: 30; 127-36. [CrossRef]

4. Schwartz D, Mayaux MJ. Female fecundity as a function of age: results of artificial insemination in 2193 nulliparous women with azoospermic husbands. Federation CECOS. N Engl J Med 1982: 306; 404-6. [CrossRef]

5. van Noord-Zaadstra BM, Looman CW, Alsbach H, Habbena JDF, te Velde ER, Karbaat J. Delaying child-bearing: effect of age on fecundity and outcome of pregnancy. Br Med J 1991: 302; 1361-5 [CrossRef]

6. Gougeon A. Regulation of ovarian follicular develoment in primates: facts and hypotheses. Endocr Rev 1996; 17: 121-55. [CrossRef]

7. Faddy MJ, Gosden RG, Gougeon A, Richardson SJ, Nelson JF. Accelerated disappearance of ovarian follicles in mid-life: Implications for forecasting menopause. Hum Reprod 1992; 7: 1342-6.

8. Hsueh AJW, Billig H, Tsafriri A. Ovarian follicle atresia: a hormonally controlled apoptotic process. Endocr Rev 1994; 15: 707-24. [CrossRef]

9. Treloar AE. Menstrual cyclicity and the premenopause. Maturitas 1981; 3: 49-64. [CrossRef]

10. van Zonneveld P, Scheffer GJ, Broekmans FJ, te Velde ER. Hormones and reproductive aging. Maturitas 2001; 38: 83-94. [CrossRef]
11. van Noord PA, Dubas JS, Dorland M, Boersma H, te Velde E. Age at natural menopause in a population-based screening cohort: the role of menarche. Fertil Steril 1997; 68: 95-102. [CrossRef]

12. Practice Committee of the American Society for Reproductive Medicine. Aging and infertility in women: a committee opinion. Fertil Steril 2002; 78: 215-9. [CrossRef]

13. Silber Z, Nagy Z, Devroey P, Camus M, Van Steirteghem AC. The effect of female age and ovarian reserve on pregnancy rate in male infertility: treatment of azoospermia with sperm retrieval and intracytoplasmic sperm injection. Hum Reprod 1997; 12: 2693-700. [CrossRef]

14. Sauer MV. The impact of age on reproductive potential: Lessons learned from oocyte donation. Maturitas 1998: 30; 221-5. [CrossRef]

15. Hansen JP. Older maternal age and pregnancy outcome: A review of the literature. Obstet Gynecol Surv 1986; 41: 726-42. [CrossRef]

16. O'Connor KA, Holman DJ, Wood JW. Declining fecundity and ovarian ageing in natural fertility populations. Maturitas 1998; 30: 127-36. [CrossRef]

17. Andersen N, Wohlfahrt J, Christens P, Olsen J, Melbye M. Maternal age and fetal loss: population based register linkage study. BMJ 2000; 24: 1708-12. [CrossRef]

18. Levran D, Ben-Shlomo I, Dor J, Ben-Rafael Z, Nebel L, Mashiach $\mathrm{S}$. Aging of endometrium and endometrium: observations on conception and abortion rates in an egg donation model. Fertil Steril 1991; 56: 1091-4

19. Macas E, Floersheim Y, Hotz E, Imthurn B, Keller PJ, Walt H. Abnormal chromosome arrangements in human oocytes. Hum Reprod 1990; 5: 703-7

20. Volarcik K, Sheean L, Goldfarb J, Wood L, Abdul-Karim FW, Hunt $\mathrm{P}$. The meiotic competence of in-vitro matured human oocytes is influenced by donor age: evidence that folliculogenesis is compromised in reproductively aged ovary. Fertil Steril 1998; 13; 154-60

21. Munne S, Cohen J, Sable D. Preimplantation genetic diagnosis for advanced maternal age and other indications. Fertil Steril 2002: 78; 234-6. [CrossRef]

22. Bancsi LF, Broekmans FJ, Mol BW, Habbema JDF, te Velde ER. Performance of basal follicle stimulating hormone in the prediction of poor ovarian response and failure to become pregnant after in vitro fertilization: a meta-analysis. Fertil Steril 2003; 79: 1091-100. [CrossRef]

23. Broekmans FJ, Kwee J, Hendriks DJ, Mol BW, Lambalk CB. A systematic review of tests predicting ovarian reserve and IVF outcome. Hum Reprod Update 2006; 12: 685-718. [CrossRef]

24. Kahapola-Arachchige KM, Hadlow N, Wardrop R, Lim EM, Walsh JP. Waiting for an elevated FSH - Too late a marker of reduced ovarian reserve? Aust N Z J Obstet Gynaecol 2012 Jul 16. [Epub ahead of print] [CrossRef]

25. van Rooij IA, Bancsi LF, Broekmans FJ, Looman CW, Habbema JD, te Velde ER. Women older than 40 years of age and those with elevated follicle-stimulating hormone levels differ in poor response rate and embryo quality in in vitro fertilization. Fertil Steril 2003; 3; 482-8. [CrossRef]

26. Scott RT, Opsahl MS, Leonardi MR, Neal GS, Illions EH, Navot D. Life table analysis of pregnancy rates in a general infertility population relative to ovarian reserve and patient age. Hum Reprod 1995; 10: $1706-10$.

27. Check JH, Peymer M, Lurie D. Effect of age on pregnancy outcome without assisted reproductive technology in women with elevated early follicular phase serum follicle-stimulating hormone levels. Gynecol Obstet Invest 1998; 45: 217-20. [CrossRef]

28. van Montfrans JM, Hoek A, van Hooff MHA, de Koning CH, Tonch N, Lambalk CB. Predictive value of basal folliclestimulating hormone concentrations in a general subfertility population. Fertil Steril 2000; 74: 97-103. [CrossRef]

29. Smotrich DB, Widra EA, Gindoff PR, Levy MJ, Hall JL, Stillman RJ. Prognostic value of day 3 estradiol on in vitro fertilization outcome. Fertil Steril 1995; 64: 1136-40 
30. Scott RT, Hoffman GE. Prognostic assessment of ovarian reserve. Fertil Steril 1995: 63; 1-11.

31. Rosencrantz MA, Wachs DS, Coffler MS, Malcom PJ, Donohue M, Chang RJ. Comparison of inhibin B and estradiol responses to intravenous FSH in women with polycystic ovary syndrome and normal women. Hum Reprod 2010; 25: 198-203. [CrossRef]

32. Seifer DB, Scott RT Jr, Bergh PA, Abrogast LK, Friedman CI, Mack $\mathrm{CK}$, et al. Women with declining ovarian reserve may demonstrate a decrease in day 3 serum inhibin B before a rise in day 3 folliclestimulating hormone. Fertil Steril 1999; 72: 63-5. [CrossRef]

33. de Vet A, Laven JS, de Jong FH, Themmen AP, Fauser BC. Antimullerian hormone serum levels: a putative marker for ovarian aging. Fertil Steril 2002; 77: 357-62 [CrossRef]

34. Seifer DB, Lambert-Messerlian G, Hogan JW, Gardiner AC, Blazar AS, Berk CA. Day 3 serum inhibin-B is predictive of assisted reproductive technologies outcome. Fertil Steril 1997; 67: 110-4. [CrossRef]

35. Marc A. Fritz, Leon Speroff. Female İnfertility. In: Marc A. Fritz Leon Speroff editors. Clinical Gynecologic Endocrinology and Infertility, 8th edition Philadelphia USA, 2011, p. 1150-2.

36. Eldar-Geva T, Ben-Chetrit A, Spitz IM, Rabinowitz R, Markowitz $\mathrm{E}$, Mimoni T, et al. Dynamic assays of inhibin B, anti-Mullerian hormone and estradiol following FSH stimulation and ovarian ultrasonography as predictors of IVF outcome. Hum Reprod 2005; 20: 3178-83. [CrossRef]

37. McIlveen M, Skull JD, Ledger WL. Evaluation of the utility of multiple endocrine and ultrasound measures of ovarian reserve in the prediction of cycle cancellation in a high-risk IVF population. Hum Reprod 2007; 22: 778-85. [CrossRef]

38. Creus M, Penarrubia J, Fabregues F, Vidal E, Carmona F, Casamitjana $\mathrm{R}$, et al. Day 3 serum inhibin B and FSH and age as predictors of assisted reproduction treatment outcome. Hum Reprod 2000; 15: 2341-6. [CrossRef]

39. Smeenk JM, Sweep FC, Zielhuis GA, Kremer JA, Thomas CM, Braat DD. Antimullerian hormone predicts ovarian responsiveness, but not embryo quality or pregnancy, after in vitro fertilization or intracyoplasmic sperm injection. Fertil Steril 2007; 87: 223-6. [CrossRef]

40. Weenen C, Laven JS, Von Bergh AR, Cranfield M, Groome NP, Visser JA, et al. Anti-Mullerian hormone expression pattern in the human ovary: potential implications for initial and cyclic follicle recruitment. Mol Hum Reprod 2004; 10: 77-83. [CrossRef]

41. Durlinger AL, Gruijters MJ, Kramer P, Karels B, Kumar Tr, Matzuk $\mathrm{MM}$, et al. Antimullerian hormone attenuates the effects of FSH on follicle development in the mouse ovary. Endocrinology 2001; 142: 4891-9. [CrossRef]

42. La Marca A, Giulini S, Orvieto R, De Leo V, Volpe A. Anti- Mullerian hormone concentrations in maternal serum during pregnancy. Human Reproduction 2005; 20: 1569-72. [CrossRef]

43. Lee MM, Donahoe PK, Hasegawa T, Silverman B, Crist GB, Best $\mathrm{S}$, et al. Mullerian inhibiting substance in humans: normal levels from infancy to adulthood. J Clin Endocrinol Metab 1996; 81: 571-6. [CrossRef]

44. Freeman EW, Sammel MD, Lin H, Gracia CR. Anti-mullerian hormone as a predictor of time to menopause in late reproductive age women. J Clin Endocrinol Metab 2012; 97: 1673-80. [CrossRef]

45. Sowers MR, Eyvazzadeh AD, McConnell D, Yosef M, Jannausch ML, Zhang D, et al. Anti-mullerian hormone and inhibin B in the definition of ovarian aging and the menopause transition. J Clin Endocrinol Metab 2008; 93: 3478-83. [CrossRef]

46. van Rooij IA, Tonkelaar I, Broekmans FJ, Looman CW, Scheffer GJ, de Jong $\mathrm{FH}$, et al. Anti-müllerian hormone is a promising predictor for the occurrence of the menopausal transition. Menopause 2004; 11: 601-6. [CrossRef]

47. van Rooij IA, Broekmans FJ, Scheffer GJ, Looman CW, Habbema JD, de Jong $\mathrm{FH}$, et al. Serum antimullerian hormone levels best reflect the reproductive decline with age in normal women with proven fertility: a longitudinal study. Fertil Steril 2005; 83: 979-87. [CrossRef]

48. de Vet A, Laven JS, de Jong FH, Themmen AP, Fauser BC. Antimullerian hormone serum levels: a putative marker for ovarian aging. Fertil Steril 2002; 77: 357-62. [CrossRef]
49. Muttukrishna S, McGarrigle H, Wakim R, Khadum I, Ranieri DM, Serhal P. Antral follicle count, anti-mullerian hormone and inhibin B: predictors of ovarian response in assisted reproductive technology? Br J Obstet Gynaecol 2005; 112: 1384-90. [CrossRef]

50. Ficicioglu C, Kutlu T, Baglam E, Bakacak Z. Early follicular antimullerian hormone as an indicator of ovarian reserve. Fertil Steril 2006; 85: 592-6. [CrossRef]

51. Gnoth C, Schuring AN, Friol K, Tigges J, Mallmann P, Godehardt E. Relevance of anti-Mullerian hormone measurement in a routine IVF program. Hum Reprod 2008; 23: 1359-65. [CrossRef]

52. Penarrubia J, Fabregues F, Manau D, Creus M, Casals G, Casamitjana $\mathrm{R}$, et al. Basal and stimulation day 5 anti-Mullerian hormone serum concentrations as predictors of ovarian response and pregnancy in assisted reproductive technology cycles stimulated with gonadotropin-releasing hormone agonist-gonadotropin treatment. Hum Reprod 2005; 20: 915-22. [CrossRef]

53. La Marca A, Sighinolfi G, Radi D, Argento C, Baraldi E, Artenisio $\mathrm{AC}$, et al. Anti Mullerian hormone (AMH) as apredictive marker in assisted reproductive technology (ART). Hum Reprod Update 2010; 16: 113-30. [CrossRef]

54. Honnma H, Baba T, Sasaki M, Hashiba Y, Oguri H, Fukunaga T, et al. Serum Anti-mullerian Hormone Levels Affect the Rate of Ongoing Pregnancy After In Vitro Fertilization. Reprod Sci 2012 Jul 18 [Epub ahead of print]. [CrossRef]

55. Broer SL, Mol BW, Hendriks D, Broekmans FJ. The role of antiMullerian hormone in prediction of outcome after IVF: comparison with the antral follicle count. Fertil Steril 2009; 91: 705-14. [CrossRef]

56. Majumder K, Gelbaya TA., Laing I, Nardo LG. The use of anti-Müllerian hormone and antral follicle count to predict the potential of oocytes and embryos. Eur J Obstet Gynecol Reprod Biol 2010; 150: 166-70. [CrossRef]

57. Silberstein T, MacLaughlin DT, Shai I, Trimarchi JR, LambertMesserlian G, Seifer DB, et al. Mullerian inhibiting substance levels at the time of HCG administration in IVF cycles predict both ovarian reserve and embryo morphology. Hum Reprod 2006; 21: 159- 63. [CrossRef]

58. Hazout A, Bouchard P, Seifer DB, Aussage P, Junca AM, CohenBacrie P. Serum antimullerian hormone/mullerian-inhibiting substance appears to be a more discriminatory marker of assisted reproductive technology outcome than follicle-stimulating hormone, inhibin B, or estradiol. Fertil Steril 2004; 82: 1323-9. [CrossRef]

59. Ebner T, Sommergruber M, Moser M, Shebl O, Schreier-Lechner E, Tews G. Basal level of anti-Mu"llerian hormone is associated with oocyte quality in stimulated cycles. Hum Reprod 2006; 21: 2022-6. [CrossRef]

60. Cupisti S, Dittrich R, Mueller A, Strick R, Stiegler E, Binder H, et al. Correlations between anti-Mullerianhormone, inhibin $\mathrm{B}$, and activin A in follicular fluid in IVF/ICSI patients for assessing the maturation and developmental potential of oocytes. Eur J Med Res 2007; 12: 604-8.

61. Fanchin R, Mendez Lozano DH, Frydman N, Gougeon A, di Clemente N, Frydman R, et al. Anti-Mullerian hormone concentrations in the follicular fluid of the preovulatory follicle are predictive of the implantation potential of the ensuing embryo obtained by in vitro fertilization. J Clin Endocrinol Metab 2007; 92: 1796-802 [CrossRef]

62. Lie Fong S, Baart EB, Martini E, Schipper I, Visser JA, Themmen AP et al. Anti-Mullerian hormone: a marker for oocyte quantity, oocyte quality and embryo quality? Reprod Biomed Online 2008; 16: 664-70. [CrossRef]

63. Ranieri DM, Quinn F, Makhlouf A, Khadum I,Ghutmi W, McGraiggle $\mathrm{H}$, et al. Simultaneous evaluation of basal follicle-stimulating hormone and 17 beta-estradiol response to gonadotropinreleasing hormone analogue stimulation: an improved predictor of ovarian reserve. Fertil Steril 1998; 70: 227-33. [CrossRef]

64. Ravhon A, Lavery S, Michael S,Donaldson M, Margara M, Trew G, et al. Dynamic assays of inhibin B and oestradiol following buserelin 
acetate administration as predictors of ovarian response in IVF. Hum Reprod 2000; 15: 2297-301.

65. Fanchin R, de Ziegler D, Olivennes F, Taieb J, Dzik A, Frydman R. Exogenous follicle stimulating hormone ovarian reserve test (EFORT): a simple and reliable screening test for detecting 'poor responders' in in-vitro fertilization. Hum Reprod 1994; 9: 1607-11.

66. Kwee J, Elting MW, Schats R, Bezemer PD, Lambalk CB, Schoemaker J. Comparison of endocrine tests with respect to their predictive value on the outcome of ovarian hyperstimulation in IVF treatment: results of a prospective randomized study. Hum Reprod 2003; 18: 1422-7. [CrossRef]

67. Christensen JT, Boldsen J, Westergaard JG. Ovarian volume in gynecologically healthy women using no contraception, or using IUD or oral contraception. Acta Obstet Gynecol Scand 1997; 76: 784-9. [CrossRef]

68. Ng EH, Yeung WS, Fong DY, Ho PC. Effects of age on hormonal and ultrasound markers of ovarian reserve in Chinese women with proven fertility. Hum Reprod 2003; 18: 2169-74. [CrossRef]

69. Erdem A, Erdem M, Biberoğlu K, Hayit O, Arslan M, Gürsoy R. Agerelated changes in ovarian volume, antral follicle counts and basal FSH in women with normal reproductive health. J Reprod Med 2002; 47: 835-40.

70. Erdem M, Erdem A, Biberoğlu K, Arslan M. Age-related changes in ovarian volume, antral follicle counts and basal follicle stimulating hormone levels: Comparison between fertile and infertile women. Gynecol Endocrinol 2003: 17; 199-205. [CrossRef]

71. Lass A, Skull J, McVeigh E, Margara R, Winston RM. Measurement of ovarian volume by transvaginal sonography before ovulation induction with human menopausal gonadotrophin for in-vitro fertilization can predict poor response. Hum Reprod 1997; 12: 294-7. [CrossRef]

72. Syrop CH, Dawson JD, Husman KJ, Sparks AE, Van Voorhis BJ. Ovarian volume may predict assisted reproductive outcomes better than follicle stimulating hormone concentration on day 3. Hum Reprod 1999; 14: 1752-6. [CrossRef]

73. Sharara FI, McClamrock HD. The effect of aging on ovarian volume measurements in infertile women. Obstet Gynecol 1999; 94: 57-60. [CrossRef]

74. Erdem M, Erdem A, Gürsoy R, Biberoğlu K. Comparison of basal and clomiphene citrate induced FSH and inhibin-B, ovarian volume and antral follicle counts as ovarian reserve tests and predictors of poor ovarian response in IVF. J Assist Reprod Genet 2004: 21; 37-45. [CrossRef]

75. Scheffer GJ, Broekmans FJ, Dorland M, Habbema JDF, Looman CWN, te Velde ER. Antral follicle counts by transvaginal ultrasonography are related to age in women with proven natural fertility. Fertil Steril 1999; 72: 845-51. [CrossRef]

76. Bancsi LF, Broekmans FJ, Eijkemans MJ, de Jong FH, Habbema JD, te Velde ER. Predictors of poor ovarian response in in vitro fertilization: a prospective study comparing basal markers of ovarian reserve. Fertil Steril 2002; 77: 328-36. [CrossRef]
77. Chang MY, Chiang CH, Hsieh TT, Soong YK, Hsu KH. Use of the antral follicle count to predict the outcome of assisted reproductive technologies. Fertil Steril 1998; 69: 505-10. [CrossRef]

78. Jayaprakasan K, Chan Y, Islam R, Haoula Z, Hopkisson J, Coomarasamy A, et al. Prediction of in vitro fertilization outcome at different antral follicle count thresholds in a prospective cohort of 1,012 women. Fertil Steril 2012 Jun 28. [Epub ahead of print] [CrossRef]

79. Engmann L, Sladkevicius P, Agrawal R, Bekir JS, Campell S, Tan SL. Value of ovarian stromal blood flow velocity measurement after pituitary suppression in the prediction of ovarian responsiveness and outcome of in vitro fertilization treatment. Fertil Steril 1999; 71: 22-9. [CrossRef]

80. Zaidi J, Barber J, Kyei-Mensah A, Bekir J, Campbell S, Tan SL. Relationship of ovarian stromal blood flow at the baseline ultrasound scan to subsequent follicular response in an in vitro fertilization program. Obstet Gynecol 1996; 88: 779-84. [CrossRef]

81. Kupesi S, Kurjak A. Predictors of IVF outcome by three-dimensional ultrasound. Hum Reprod 2002; 17: 950-5. [CrossRef]

82. Järvelä IY, Sladkevicius P, Kelly S, Ojha K, Campbell S, Nargund G. Quantification of ovarian power Doppler signal with threedimensional ultrasonography to predict response during in vitro fertilization. Obstet Gynecol 2003; 102: 816-22. [CrossRef]

83. Jadaon JE, Ben-Ami M, Haddad S, Radin O, Bar-Ami S, Younis JS. Prospective evaluation of early follicular ovarian stromal blood flow in infertile women undergoing IVF-ET treatment. Gynecol Endocrinol 2012; 28: 356-9. [CrossRef]

84. Lass A, Silye R, Abrams DC, Kraus T, Hovatta O, Margara R, et al. Follicular density in ovarian biopsy ofinfertile women: a novel method to assess ovarian reserve. Hum Reprod 1997; 12: 1028-31. [CrossRef]

85. Gulekli B, Bulbul Y, Onvural A, Yorukoglu K, Posacı C, Demir N, et al. Accuracy of ovarian reserve tests. Hum Reprod 1999; 14: 2822-6.

86. Qu J, Godin PA, Nisolle M, Donnez J. Distribution and epidermal growth factor receptor expression of primordial follicles in human ovarian tissue before and after cryopreservation. Hum Reprod $2000 ; 15 ; 302-10$. [CrossRef]

87. Muttukrishna S, McGarrigle H, Wakim R, Khadum I, Ranieri DM, Serhal P. Antral follicle count, anti-mullerian hormone and inhibin $\mathrm{B}$ : predictors of ovarian response in assisted reproductive technology? BJOG 2005; 112: 1384-90. [CrossRef]

88. Verhagen TE, Hendriks DJ, Bancsi LF, Mol BW, Broekmans FJ. The accuracy of multivariate models predicting ovarian reserve and pregnancy after in vitro fertilization: a meta-analysis. Hum Reprod Update 2008; 14: 95-100. [CrossRef]

89. Kunt C, Ozaksit G, Keskin Kurt R, Cakir Gungor AN, Kanat-Pektas $\mathrm{M}$, Kilic S, et al. Anti-Mullerian hormone is a better marker than inhibin $\mathrm{B}$, follicle stimulating hormone, estradiol or antral follicle count in predicting the outcome of in vitro fertilization. Arch Gynecol Obstet 2011; 283: 1415-21. [CrossRef]

90. Gurtcheff SE, Klein NA. Diminished ovarian reserve and infertility. Clin Obstet Gynecol 2011; 54: 666-74. [CrossRef] 